\title{
Facial anthropometric analysis of a healthy group of young Brazilian adults by means of stereophotogrammetry technique
}

\author{
Análise antropométrica facial de um grupo de jovens adultos brasileiros saudáveis por meio da \\ técnica da estereofotogrametria
}

\begin{abstract}
Alvaro Augusto JUNQUEIRA JÚNIOR a*, Laís Valencise MAGRIa, Melissa de Oliveira MELCHIORa, Ana Maria Bettoni RODRIGUES DA SILVAª Marco Antônio Moreira RODRIGUES DA SILVA ${ }^{\mathrm{a}}$
\end{abstract}

${ }^{\text {a} F a c u l d a d e ~ d e ~ O d o n t o l o g i a ~ d e ~ R i b e i r a ̃ o ~ P r e t o, ~ U S P ~-~ U n i v e r s i d a d e ~ d e ~ S a ̃ o ~ P a u l o, ~ R i b e i r a ̃ o ~ P r e t o, ~ S P, ~ B r a s i l ~}$

\begin{abstract}
Resumo
Introdução: Antropometria é a ciência responsável por medir o peso, tamanho e proporções do corpo humano, fornecendo informações objetivas e confiáveis para caracterizar variações e dismorfismos fenotípicos. Entre os novos métodos de análise facial, a técnica da estereofotogrametria tem mostrado excelentes resultados devido o uso de um grupo de câmeras capazes de fotografar sujeitos em múltiplos ângulos. Objetivo: Os objetivos deste estudo foram: (1) analisar o perfil facial de um grupo de jovens adultos saudáveis brasileiros, entre 18 e 30 anos, (2) definir valores comuns entre os sujeitos, (3) criar uma base de dados de medidas faciais de uma porção desta população jovem adulta de brasileiros para ser utilizada em trabalhos futuros, e (4) testar a precisão e repetibilidade do equipamento Vectra $\mathrm{M}^{\circledR}$. Material e método: Sessenta jovens adultos brasileiros participaram deste estudo, 30 homens e 30 mulheres. Pontos de referência craniométricos temporários foram realizados em tecido mole, e estes sujeitos foram fotografados pela técnica da estereofotogrametria. Trinta pontos de referência foram usados para realizar as medições $(\mathrm{em} \mathrm{mm})$ de 35 distâncias. A repetibilidade do equipamento foi testada em $20 \%$ da amostra (12 sujeitos). Resultado: Os valores entre a primeira e a segunda aquisição foram estatisticamente $(\mathrm{p}<0,05)$ similares para todas as 35 distancias analisadas. Os achados possibilitaram a criação de um banco de dados confiável contendo distâncias de uma porção da população jovem adulta saudável brasileira. Além disso, as distâncias Tr-N, N-Sn, Ls-Sto, Sto-Li, En[r]-En[1] e Prn-Sn não foram estatisticamente diferentes entre o grupo de homens (GM) e o grupo de mulheres (GW), enquanto as outras 29 distâncias foram significativamente maiores em GM. Conclusão: A técnica e os métodos empregados neste estudo possibilitaram análise objetiva do perfil facial de um grupo de jovens adultos saudáveis brasileiros, e o equipamento Vectra $\mathrm{M}^{\circledR}$ mostrou alto nível de precisão e reprodutibilidade.
\end{abstract}

Descritores: Estereofotogrametria; antropometria; face; população brasileira.

\begin{abstract}
Introduction: Anthropometry is the science responsible for measuring the weight, size, and proportions of the human body, providing valuable and objective insights into how to characterize phenotypic variation and dysmorphology. Among the newer methods for facial analysis, the stereophotogrammetry technique has shown excellent results given its use of a group of fast cameras that photograph subjects from multiple angles. Objective: The aims of the present study were: (1) to analyze the facial profile of a group of healthy young Brazilian adults, between 18 and 30 years of age, (2) to define common facial values among the subjects, (3) to create a database of facial measurements of a portion of this young healthy Brazilian population to be used in future works, and (4) to test the precision and repeatability of the Vectra $M 3^{\circledR}$ equipment. Material and method: Sixty healthy young Brazilian adults participated in the study, 30 males and 30 females. Temporary craniometrical landmarks were performed in soft tissue, and those subjects underwent image capturing by the stereophotogrammetry technique. Thirty landmarks were used to take the measurements (in $\mathrm{mm}$ ) of 35 distances. The equipment repeatability was tested in $20 \%$ of the sample (i.e., 12 subjects). Result: The values between the first and second acquisitions were statistically $(\mathrm{p}<0.05)$ similar for all 35 distances analyzed. The findings allowed the creation of a reliable database containing facial distances of a portion of the young healthy Brazilian population. In addition, the distances Tr-N, N-Sn, Ls-Sto, Sto-Li, En[r]-En[l] and Prn-Sn were not statistically different for the group of men (GM) and the group of women (GW), while the other 29 distances were significantly greater in GM. Conclusion: The technique and methods employed in the study yielded objective analyses of the facial profile of this group of healthy young Brazilian adults, and the equipment Vectra $\mathrm{M} 3^{\circledR}$ showed a high level of precision and repeatability.
\end{abstract}

Descriptors: Stereophotogrammetry; anthropometry; face; Brazilian population. 


\section{INTRODUCTION}

Anthropometry is the science responsible for measuring the weight, size, and proportions of the human body, providing valuable and objective insights into how to characterize phenotypic variation and dysmorphology ${ }^{\star *}$. It provides precise diagnoses to several syndromes and allows the evaluation and planning of orthodontic and surgical treatments, calculating normal and abnormal growths ${ }^{1}$. Traditionally, anthropometric measurements have been acquired through direct techniques from a subject in a clinical set by using calipers and metric tapes to measure distances or arches between landmarks ${ }^{\star *}$.

Along with other scientific and technological advances, newer techniques, such as laser scans, magnetic resonance imaging, ultrasounds ${ }^{*}$, contact digitalization, and stereophotogrammetry, provide significant changes on the diagnosis process, as these are considered to be non-invasive methods of facial analysis ${ }^{1-3}$. Furthermore, analogic data have become digital, opening the possibility for quick, precise, and non-radioactive image captures, which can be simultaneously stored for future analysis as well as shared with patients and colleagues ${ }^{1,2,4-10}$. Among the newer methods for facial analysis, the stereophotogrammetry technique has shown excellent results given its use of a group of fast cameras that photograph subjects from multiple angles. These high-speed image captures, which occur simultaneously, reduce the movement effect of the subject. Moreover, there is no modification in the soft tissue position because there is no need for direct contact with the subject during the image capturing. This way, distortions and measurement errors secondary to soft tissue manipulation can be avoided, making this a reliable, non-invasive technique $e^{2,7,11-13}$

The various ethnic peculiarities of hard and soft tissues of the human face (i.e., facial morphology) characterize different populations and can be determined through $3 \mathrm{D}$ images. The average of these measurements from facial 3D images represents the facial morphology of soft tissue from adults and can be used to assist with diagnoses and the treatment regimens of patients from different countries, as it shows population's singularities and soft tissue structures ${ }^{10}$. Several studies have, in fact, also aimed at creating facial profiles of different racial groups ${ }^{14-19}$. In Brazil, such mapping of facial profiles has not been conducted, and stereophotogrammetry techniques could certainly provide accurate measurements of the populations' facial traits for comparison between the country's different regions as well as to other international studies. Accordingly, the aim of this study was to analyze the facial profile of two groups consisting of healthy young Brazilian adults through the stereophotogrammetric technique in order to compare male and female subjects, define facial common values between them, as well as to test the reliability of the Vectra $\mathrm{M} 3^{\circledR}$ stereophotogrammetry equipment.

\footnotetext{
** Farkas L. Examination. In: Farkas L, editor. Anthropometry of the head and face. 2nd ed. New York: Raven Press; 1994. p. 3-56.
}

\section{MATERIAL AND METHOD}

The present study was conducted at the Laboratory of Electromyographic Research of the Stomatognathic System at the Restorative Department of the School of Dentistry of Ribeirão Preto, University of São Paulo (Ribeirão Preto, SP, Brazil), being approved by the local Ethic Committee (CAAE number: 08874612.3.0000.5419). Sixty-four subjects were evaluated at the beginning of the study, and 60 of them were selected for facial analysis (the criteria used to select participants are described below). Two groups were created: the Group of Men (GM) and the Group of Women (GW), each one with 30 volunteers. The subjects were selected independently of their birthplace, and their participation was voluntary. All participants were informed of the objectives and methods of the study and signed the study's informed consent following the Brazilian human research ethics committee.

In order to participate in the study, the subjects had to be Brazilian, healthy, and between 18 and 30 years of age. The following individuals were excluded from the study: subjects who had missing teeth (except for extractions due to orthodontic planning), peripheral and/or central neurologic disorders, prior major trauma and/or tumors in the craniofacial area, partial or total removable dental prosthesis, severe horizontal or vertical trespasses $(>5 \mathrm{~mm})$, evident craniofacial discrepancies, and clear presence of temporomandibular disorders, as well as patients who were undergoing orthodontic treatment.

The established landmarks used in the measurements were suggested by Farkas* in 1994, except for landmarks Chk[r] and Chl[1], positioned according to Ferrario ${ }^{20}$, and the landmark Gn (Gnation).The marking of the landmarks was performed with a black liner (O Boticário ${ }^{\circledR}$, Brazil) in all 60 subjects. This stage lasted, in average, 5 minutes per subject.

The landmarks Ex[r], Ex[1], En[r], En[1], $\mathrm{Ch}[\mathrm{r}], \mathrm{Ch}[1]$ and Sto were not marked with the liner. Those landmarks were positioned directly in the software after the image was captured since they are well delimited by facial anatomy and their reproducibility is reliable ${ }^{21}$. Figures 1 and 2 show the landmarks and their positions. The black dots are the landmarks where the liner was used, and the white ones are the landmarks that were entered directly on the computer.

The equipment used for the image capture was the Vectra M3 ${ }^{\circledR}$ (Canfield, NY, USA). After the correct positioning of the subject, he/she was asked to relax the facial musculature to avoid positioning alterations of the soft tissue. Once the quality of the image had been verified, another capture was made in order to perform a repeatability test and verify the reliability of the equipment. The distances between the landmarks were measured in straight lines, and the values were expressed in millimeters.

Thirty-five linear distances were obtained, comprising several areas of the face. The use of "[r]" and "[l]" by the side of the landmark's abbreviation represents its side (right and left, respectively). Each distance consisted of two landmarks, related to its beginning and end. The distance Ex-En (related to eye fissure length) was obtained by dividing the sum of the distances of both eyes $(\operatorname{Ex}[r]-E n[r]$ $+\operatorname{Ex}[\mathrm{r}]-\mathrm{En}[1])$ by two for each subject. The distances and their 


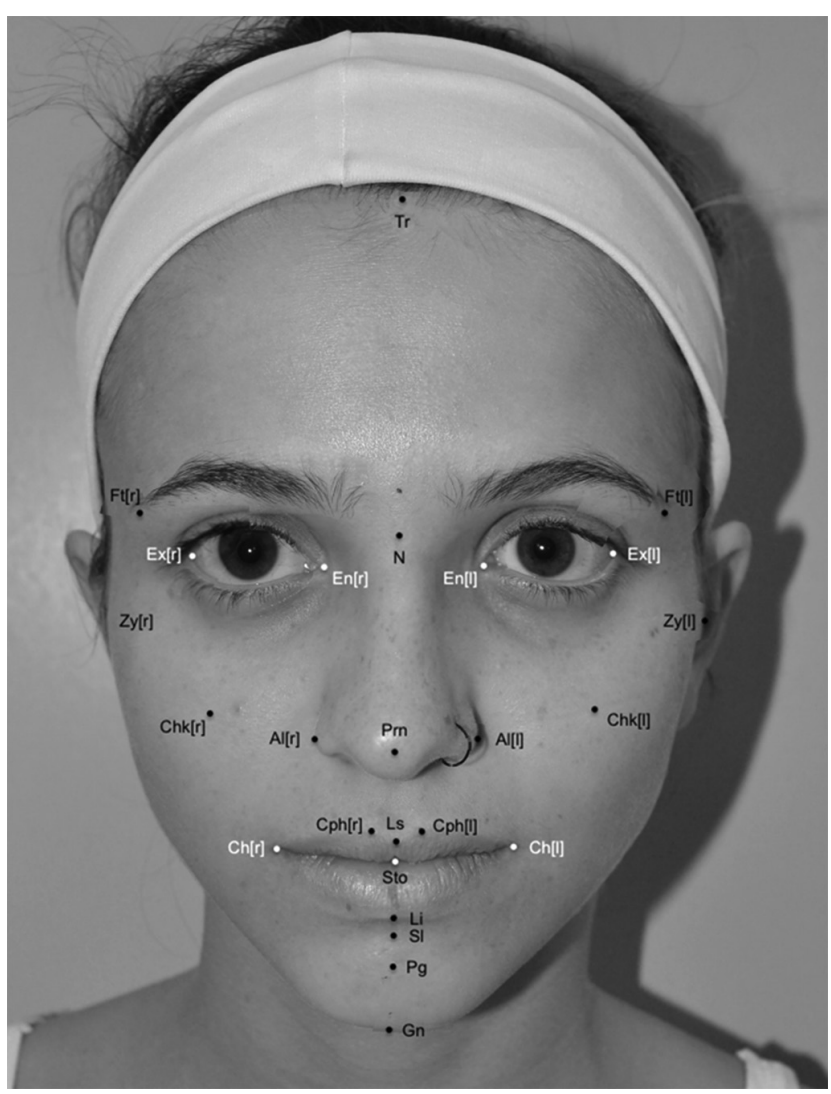

Figure 1. Frontal view of the face, showing the used landmarks.

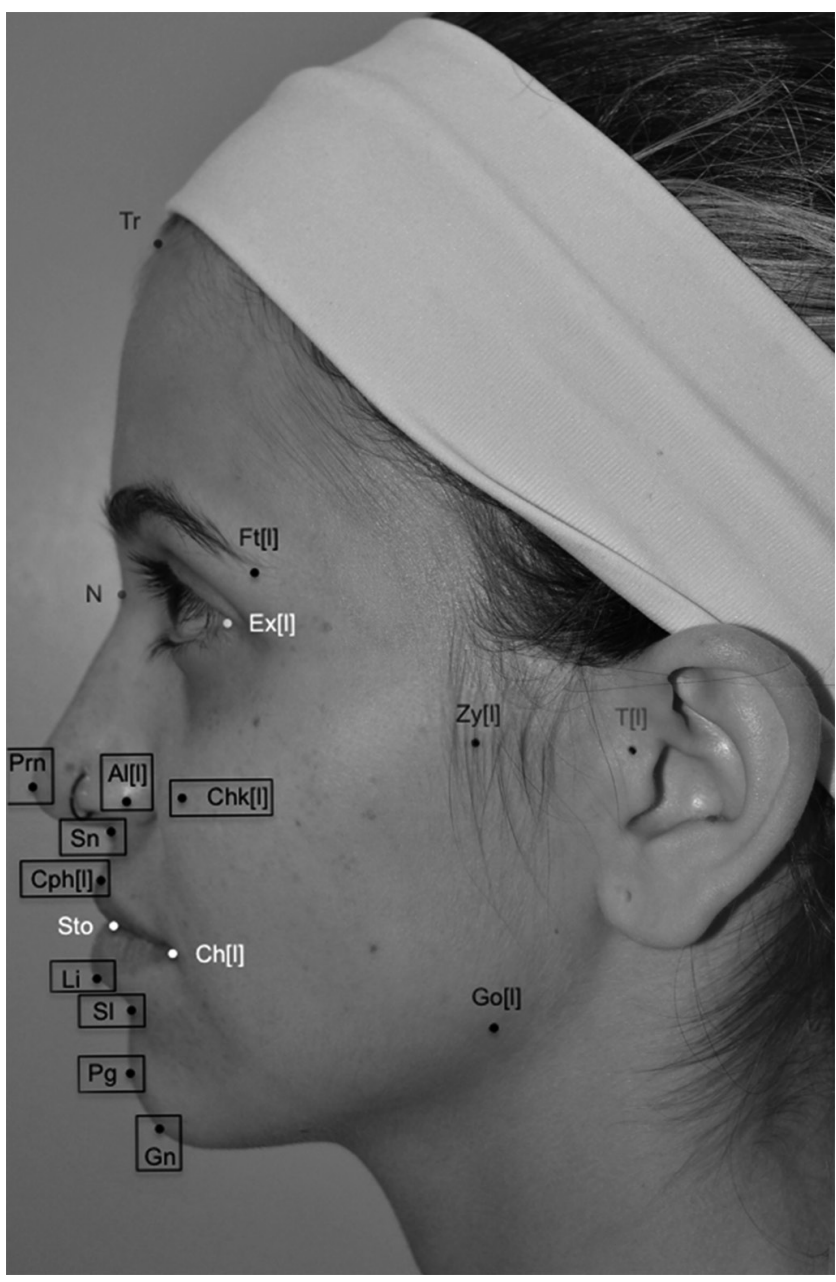

Figure 2. Lateral view of the face, showing the used landmarks. definitions were described by Farkas ${ }^{1}$. For the comparison between the GM and GW groups, the T-student Test was used, considering $\mathrm{p}<0.05$ as statistical significance.

In the repeatability test, parametrical statistics were applied for the distances with normal distribution: T-student Tests, considering 5\% as significance level. For the distances with non-normal distribution (A[r]-Al[1], Sn-Sto, Tr-Gn and Chk[r]-Chk[1]), a non-parametrical statistic, Mann-Whitney Test, was employed.

\section{RESULT}

The statistical results (average, standard deviation [S.D.], median, maximum and minimum) are listed in Tables 1 and 2 (men, women). When the measurements were compared between the groups GM and GW, only the distances Tr-N, N-Sn, Ls-Sto, En[r]-En[l] and Prn-Sn were very similar between subjects for both genders, as they did not reach significant statistical differences (Table 3). Further, Table 3 shows the results of the repeatability test, which include two images that were made with 12 subjects (i.e., the first and second images of each individual). All distances had high $p$ values, indicating that the equipment reliability was high.

\section{DISCUSSION}

Several works ${ }^{10,14-18,22}$ have anthropometrically analyzed facial features of different populations. However, discussions between those studies and the present work are somewhat difficult to make due to the notable genotypic (and thereby phenotypic) variation between races. In other words, given the ethnic diversity of Brazilians, comparisons between the present findings and studies of other populations around the world would be pointless. An interesting comparison could be done after studying other Brazilian groups (from North, Northeast, South, Central West), what is the aim of future works.

The Brazilian population is extremely diverse as Italian, German, Japanese, and Portuguese groups, among other nationalities, immigrated to Brazil in the beginning of its colonization in the 16 th century and after World Wars I and II. The number of African descendants is also representative since slavery was present in Brazil during colonial times, and slave trafficking of African populations was a common and legal practice until 1850.

When both experimental groups (GM and GW) were compared, only six distances did not show statistical differences between them: Tr-N (upper third of the face), N-Sn (middle third of the face), Ls-Sto (upper vermilion height), Sto-Li (lower vermilion height), En[r]-En[1] (intercanthal width), and Prn-Sn (nose protrusion). These findings suggest that most landmark distances between GM and GW have clear differences between those groups, and these differences are partially responsible for male and female characteristics. The lower third of the face (Sn-Gn) was the only third of the face with statistical differences between GM and GW, being the primary reason for the discrepancy in facial height (Tr-Gn) between both groups. The distances Go[r]-Go[1] (width of the mandible), T-Go (height of the mandible ramus, for both 
Table 1. Average, standard deviation (S.D.), median, maximum and minimum values of each distance (in mm). Men group ( $\mathrm{n}=30$ )

\begin{tabular}{|c|c|c|c|c|c|}
\hline Distance & Average & SD & Median & Maximum & Minimum \\
\hline $\operatorname{Ex}[\mathbf{r}]-\operatorname{Ex}[1]$ & 88.85 & 3.72 & 89.04 & 97.16 & 79.93 \\
\hline $\mathbf{T}[\mathbf{r}]-\mathbf{T}[\mathbf{l}]$ & 147.57 & 6.93 & 146.57 & 163.17 & 133.32 \\
\hline $\mathrm{Zy}[\mathbf{r}]-\mathrm{Zy}[\mathbf{l}]$ & 144.47 & 8.16 & 143.44 & 166.00 & 132.03 \\
\hline Go[r]-Go[l] & 120.06 & 8.20 & 119.49 & 143.75 & 106.50 \\
\hline $\mathrm{Ch}[\mathbf{r}]-\mathrm{Ch}[\mathbf{l}]$ & 51.76 & 3.31 & 51.93 & 59.70 & 46.17 \\
\hline $\operatorname{Tr}-\mathbf{N}$ & 68.72 & 8.52 & 67.67 & 87.40 & 53.55 \\
\hline N-Sn & 52.65 & 3.17 & 53.05 & 58.28 & 47.54 \\
\hline $\mathrm{T}[\mathbf{r}]-\mathrm{Go}[\mathbf{r}]$ & 67.04 & 5.93 & 66.49 & 78.78 & 56.78 \\
\hline $\mathrm{T}[\mathbf{1}]-\mathrm{Go}[\mathbf{1}]$ & 66.70 & 5.71 & 67.06 & 78.35 & 51.85 \\
\hline$N-T[r]$ & 122.31 & 5.22 & 121.84 & 134.04 & 112.40 \\
\hline $\mathrm{N}-\mathrm{T}[\mathbf{1}]$ & 122.46 & 5.01 & 122.03 & 132.59 & 112.18 \\
\hline Sn-T[r] & 129.73 & 4.77 & 130.28 & 137.08 & 117.68 \\
\hline Sn-T[1] & 129.86 & 5.06 & 130.92 & 136.22 & 117.63 \\
\hline $\operatorname{Pg}-\mathrm{T}[\mathrm{r}]$ & 146.64 & 6.16 & 147.05 & 158.75 & 129.99 \\
\hline $\operatorname{Pg}-\mathrm{T}[1]$ & 146.16 & 6.54 & 147.09 & 157.86 & 130.90 \\
\hline Pg-Go[r] & 99.88 & 5.21 & 100.53 & 109.94 & 87.92 \\
\hline Pg-Go[1] & 100.21 & 4.99 & 100.70 & 110.07 & 86.45 \\
\hline $\mathrm{Ft}[\mathbf{r}]-\mathrm{Ft}[\mathbf{l}]$ & 119.12 & 5.10 & 119.91 & 127.28 & 111.18 \\
\hline $\operatorname{Al}[\mathbf{r}]-\mathbf{A l}[\mathbf{l}]$ & 37.00 & 3.42 & 35.96 & 45.35 & 31.76 \\
\hline $\mathrm{Cph}[\mathbf{r}]-\mathrm{Cph}[\mathrm{l}]$ & 13.07 & 1.75 & 13.10 & 16.81 & 9.87 \\
\hline Sn-Ls & 16.48 & 2.37 & 16.90 & 20.19 & 11.75 \\
\hline Ls-Sto & 8.77 & 1.80 & 8.36 & 12.07 & 5.58 \\
\hline Sn-Sto & 23.82 & 2.14 & 23.98 & 27.81 & 19.82 \\
\hline Sto-Sl & 19.46 & 3.15 & 19.13 & 27.39 & 13.84 \\
\hline Li-Sl & 11.02 & 2.40 & 10.38 & 15.89 & 5.89 \\
\hline Sto-Li & 10.73 & 3.09 & 10.48 & 23.04 & 3.99 \\
\hline $\operatorname{En}[\mathbf{r}]-\operatorname{En}[1]$ & 32.85 & 2.91 & 32.95 & 40.55 & 27.48 \\
\hline En-Ex & 28.68 & 1.48 & 28.95 & 30.82 & 24.34 \\
\hline N-Prn & 46.69 & 3.86 & 46.63 & 54.31 & 39.39 \\
\hline Prn-Sn & 19.62 & 2.24 & 19.03 & 24.11 & 16.30 \\
\hline Sl-Gn & 24.98 & 2.66 & 25.06 & 29.96 & 20.76 \\
\hline Tr-Gn & 185.62 & 10.57 & 185.83 & 204.54 & 162.30 \\
\hline Sn-Gn & 67.69 & 5.03 & 66.88 & 79.96 & 56.96 \\
\hline Sto-Gn & 44.10 & 3.96 & 43.30 & 54.32 & 35.83 \\
\hline $\operatorname{Chk}[\mathbf{r}]-\operatorname{Chk}[\mathbf{l}]$ & 85.27 & 4.83 & 84.15 & 95.80 & 77.84 \\
\hline $\operatorname{Chk}[\mathbf{r}]-\operatorname{Chk}[1]$ & 85.27 & 4.83 & 84.15 & 95.80 & 77.84 \\
\hline
\end{tabular}


Table 2. Average, standard deviation (S.D.), median, maximum and minimum values of each distance (in mm). Women group ( $\mathrm{n}=30$ )

\begin{tabular}{|c|c|c|c|c|c|}
\hline Distance & Average & S.D. & Median & Maximum & Minimum \\
\hline $\operatorname{Ex}[\mathbf{r}]-\operatorname{Ex}[\mathbf{l}]$ & 85.98 & 3.46 & 85.81 & 92.60 & 78.27 \\
\hline $\mathbf{T}[\mathbf{r}]-\mathbf{T}[\mathbf{l}]$ & 137.59 & 4.99 & 136.73 & 149.49 & 130.03 \\
\hline $\mathrm{Zy}[\mathbf{r}]-\mathrm{Zy}[\mathbf{l}]$ & 137.03 & 6.38 & 136.59 & 152.31 & 125.96 \\
\hline Go[r]-Go[l] & 114.85 & 7.38 & 112.12 & 134.07 & 104.87 \\
\hline $\operatorname{Ch}[\mathbf{r}]-\mathrm{Ch}[1]$ & 49.10 & 2.73 & 48.99 & 54.66 & 42.48 \\
\hline Tr-N & 66.84 & 8.06 & 67.38 & 82.17 & 47.93 \\
\hline N-Sn & 51.21 & 3.45 & 50.70 & 57.19 & 44.46 \\
\hline $\mathrm{T}[\mathbf{r}]-\mathbf{G o}[\mathbf{r}]$ & 54.75 & 5.69 & 54.57 & 69.38 & 41.88 \\
\hline $\mathrm{T}[\mathbf{1}]-\mathrm{Go}[\mathbf{l}]$ & 55.63 & 4.31 & 55.27 & 66.19 & 44.55 \\
\hline $\mathbf{N}-\mathbf{T}[\mathbf{r}]$ & 113.52 & 3.89 & 113.21 & 122.18 & 105.23 \\
\hline $\mathrm{N}-\mathrm{T}[\mathbf{l}]$ & 113.31 & 4.07 & 112.70 & 125.33 & 106.20 \\
\hline Sn-T[r] & 118.39 & 4.41 & 118.47 & 126.49 & 107.85 \\
\hline Sn-T[1] & 118.25 & 3.85 & 117.42 & 126.67 & 111.29 \\
\hline $\operatorname{Pg}-\mathrm{T}[\mathrm{r}]$ & 132.44 & 6.23 & 132.09 & 145.57 & 121.73 \\
\hline $\mathrm{Pg}-\mathrm{T}[\mathrm{l}]$ & 132.20 & 5.62 & 132.23 & 147.07 & 120.70 \\
\hline Pg-Go[r] & 94.67 & 6.10 & 96.33 & 103.17 & 78.75 \\
\hline Pg-Go[1] & 93.54 & 5.91 & 93.80 & 103.11 & 78.85 \\
\hline $\mathbf{F t}[\mathbf{r}]-\mathbf{F t}[\mathbf{l}]$ & 113.25 & 5.58 & 114.36 & 127.96 & 102.90 \\
\hline $\operatorname{Al}[\mathbf{r}]-\mathbf{A l}[\mathbf{l}]$ & 32.68 & 2.44 & 32.36 & 40.63 & 28.98 \\
\hline $\mathrm{Cph}[\mathbf{r}]-\mathrm{Cph}[\mathbf{1}]$ & 11.21 & 1.52 & 11.03 & 13.90 & 8.12 \\
\hline Sn-Ls & 14.64 & 2.35 & 14.32 & 18.87 & 10.47 \\
\hline Ls-Sto & 8.30 & 1.48 & 8.40 & 11.33 & 4.63 \\
\hline Sn-Sto & 21.67 & 1.97 & 21.36 & 25.62 & 17.70 \\
\hline Sto-SI & 17.69 & 1.81 & 17.32 & 20.73 & 14.27 \\
\hline Li-Sl & 9.10 & 1.99 & 9.56 & 12.14 & 4.06 \\
\hline Sto-Li & 10.47 & 1.66 & 10.41 & 14.05 & 7.16 \\
\hline $\operatorname{En}[\mathbf{r}]-\operatorname{En}[1]$ & 32.26 & 1.84 & 32.16 & 36.25 & 29.17 \\
\hline En-Ex & 27.62 & 1.39 & 27.45 & 30.36 & 24.81 \\
\hline N-Prn & 44.75 & 3.20 & 44.46 & 50.51 & 37.88 \\
\hline Prn-Sn & 18.86 & 2.65 & 18.77 & 25.15 & 14.50 \\
\hline Sl-Gn & 21.98 & 3.44 & 22.14 & 27.09 & 14.88 \\
\hline Tr-Gn & 175.72 & 10.18 & 176.19 & 197.22 & 157.30 \\
\hline Sn-Gn & 60.64 & 4.71 & 60.63 & 72.73 & 49.62 \\
\hline Sto-Gn & 39.29 & 4.43 & 39.14 & 53.77 & 30.08 \\
\hline $\operatorname{Chk}[\mathbf{r}]-\operatorname{Chk}[1]$ & 82.44 & 3.82 & 81.60 & 89.61 & 76.69 \\
\hline
\end{tabular}


Table 3. $p$ values for each distance comparing men and women measurements $(n=60)$ and $p$ value after repeatability test $(n=12)$

\begin{tabular}{|c|c|c|}
\hline Distance & GM vs GW $p$ value & $\begin{array}{c}\text { Repeatability test } \\
p \text { value }\end{array}$ \\
\hline $\operatorname{Ex}[\mathbf{r}]-\operatorname{Ex}[1]$ & $\mathrm{p}=0.003$ & 0.96 \\
\hline $\mathbf{T}[\mathbf{r}]-\mathbf{T}[\mathbf{l}]$ & $\mathrm{p}=0.0001$ & 0.97 \\
\hline $\mathrm{Zy}[\mathbf{r}]-\mathrm{Zy}[\mathbf{l}]$ & $\mathrm{p}=0.0002$ & 0.99 \\
\hline Go[r]-Go[l] & $\mathrm{p}=0.01$ & 0.96 \\
\hline $\mathrm{Ch}[\mathbf{r}]-\mathrm{Ch}[\mathbf{1}]$ & $\mathrm{p}=0.001$ & 0.79 \\
\hline Tr-N & $\mathrm{p}=0.38$ & 0.97 \\
\hline N-Sn & $\mathrm{p}=0.09$ & 0.99 \\
\hline$T[\mathbf{r}]-\mathbf{G o}[\mathbf{r}]$ & $\mathrm{p}<0.0001$ & 0.99 \\
\hline $\mathrm{T}[\mathbf{1}]-\mathrm{Go}[\mathbf{1}]$ & $\mathrm{p}<0.0001$ & 0.93 \\
\hline $\mathbf{N}-\mathbf{T}[\mathbf{r}]$ & $\mathrm{p}<0.0001$ & 0.97 \\
\hline N-T[1] & $\mathrm{p}<0.0001$ & 0.90 \\
\hline $\mathrm{Sn}-\mathrm{T}[\mathrm{r}]$ & $\mathrm{p}<0.0001$ & 0.99 \\
\hline Sn-T[1] & $\mathrm{p}<0.0001$ & 0.90 \\
\hline $\operatorname{Pg}-\mathrm{T}[\mathbf{r}]$ & $\mathrm{p}<0.0001$ & 0.94 \\
\hline Pg-T[1] & $\mathrm{p}<0.0001$ & 0.89 \\
\hline Pg-Go[r] & $\mathrm{p}<0.0001$ & 0.94 \\
\hline Pg-Go[l] & $\mathrm{p}<0.0001$ & 0.98 \\
\hline $\mathrm{Ft}[\mathbf{r}]-\mathrm{Ft}[\mathbf{l}]$ & $\mathrm{p}<0.0001$ & 0.99 \\
\hline $\operatorname{Al}[\mathbf{r}]-\mathbf{A l}[\mathbf{l}]$ & $\mathrm{p}<0.0001$ & 0.81 \\
\hline $\mathrm{Cph}[\mathbf{r}]-\mathrm{Cph}[\mathbf{l}]$ & $\mathrm{p}<0.0001$ & 0.95 \\
\hline Sn-Ls & $\mathrm{p}=0.001$ & 0.90 \\
\hline Ls-Sto & $\mathrm{p}=0.27$ & 0.97 \\
\hline Sn-Sto & $\mathrm{p}=0.0002$ & 0.95 \\
\hline Sto-S1 & $\mathrm{p}=0.01$ & 0.94 \\
\hline Li-Sl & $\mathrm{p}=0.01$ & 0.94 \\
\hline Sto-Li & $\mathrm{p}=0.69$ & 0.72 \\
\hline $\operatorname{En}[\mathbf{r}]-\operatorname{En}[\mathbf{l}]$ & $\mathrm{p}=0.35$ & 0.92 \\
\hline En-Ex & $\mathrm{p}=0.05$ & 0.97 \\
\hline N-Prn & $\mathrm{p}=0.03$ & 0.96 \\
\hline Prn-Sn & $\mathrm{p}=0.23$ & 0.98 \\
\hline Sl-Gn & $\mathrm{p}=0.0004$ & 0.99 \\
\hline Tr-Gn & $\mathrm{p}=0.005$ & 0.95 \\
\hline Sn-Gn & $\mathrm{p}<0.0001$ & 0.97 \\
\hline Sto-Gn & $\mathrm{p}=0.001$ & 0.96 \\
\hline $\operatorname{Chk}[\mathbf{r}]-\operatorname{Chk}[1]$ & $\mathrm{p}=0.01$ & 0.86 \\
\hline
\end{tabular}

sides), and Pg-T (protrusion of the inferior portion of the lower third of the face, for both sides) were statistically greater in GM. This shows that mandibular growth is more pronounced among men, a characteristic commonly linked to masculine facial features.

It is interesting to point out that as the average values of facial size in men are higher that in women in coronal, transversal, and sagittal planes (Tr-Gn, Zy[r]-Zy[1] and T[r-l]-Sn), distances that did not show statistical differences between groups, like Ls-Sto, Sto-Li, En[r]-En[1] and Prn-Sn, may appear to be more prominent in women. In other words, as GM shows higher average values for facial size, the equivalent distances for GW tend to present a range proportionally higher in women's faces.

Other characteristics linked to specific areas of the face, such as nose length and width, mouth width, eye fissure length, distance between the external corners of the eyes, among others, showed significant differences between both groups, suggesting that higher values for those measurements are commonly related to masculine faces.

\section{CONCLUSION}

Even though the findings from the present study as well as the comparisons to previous research presented in the discussion are certainly important, they should be treated with caution since the groups studied here do not exhaustively represent the entire Brazilian population. Future studies, seeking data from populations from other regions of Brazil, need to be conducted so that more anthropometric data can be mapped, and thus allow for facial values for the Brazilian population to begin to be represented in a more comprehensive manner.

Nonetheless, despite the limitations of this study, it was possible to analyze objectively the facial profile of a group of healthy young Brazilian adults. Of all 35 distances analyzed in both groups included in the study (i.e., one male and one female group), only six of them were not statistically different between men and women. These were: the upper third of the face $(\operatorname{Tr}-\mathrm{N})$, middle third of the face $(\mathrm{N}-\mathrm{Sn})$, upper vermilion height (Ls-Sto), the lower vermilion height (Sto-Li), intercanthal width $(\operatorname{En}[\mathrm{r}]-\operatorname{En}[1])$, and nose protrusion (Prn-Sn). This suggests that those distances appear to be more prominent in women, not because of their size (which is relatively statistically equal to men's), but because they are proportionally greater in women due to females' overall smaller facial distances. Theother 29 distances examined were statistically greater in men. Finally, the Vectra M3 proved to be highly reliable, as none of the 35 distances presented any significant differences between the first and second image capturing in all 12 analyzed subjects ( $20 \%$ of the sample). This finding corroborates previous research that indicates the equipment reliability. ${ }^{1}$

This study yielded the first findings for facial profiles of a portion of the Brazilian population (i.e., young and healthy adults between 18 and 30 years of age), and future research calls for further investigations of other Brazilian groups. 


\section{REFERENCES}

1. Menezes M, Rosati R, Ferrario VF, Sforza C. Accuracy and reproducibility of a 3-dimensional stereophotogrammetric imaging system. J Oral Maxillofac Surg. 2010 Sep;68(9):2129-35. http://dx.doi.org/10.1016/j.joms.2009.09.036. PMid:20646812.

2. Weinberg SM, Scott NM, Neiswanger K, Brandon CA, Marazita ML. Digital three-dimensional photogrammetry: evaluation of anthropometric precision and accuracy using a Genex 3D camera system. Cleft Palate Craniofac J. 2004 Sep;41(5):507-18. http://dx.doi.org/10.1597/03-066.1. PMid:15352857.

3. Sforza C, Laino A, D’Alessio R, Dellavia C, Grandi G, Ferrario VF. Three-dimensional facial morphometry of attractive children and normal children in the deciduous and early mixed dentition. Angle Orthod. 2007 Nov;77(6):1025-33. http://dx.doi.org/10.2319/100206-400.1. PMid:18004919.

4. Aldridge K, Boyadjiev SA, Capone GT, DeLeon VB, Richtsmeier JT. Precision and error of three-dimensional phenotypic measures acquired from 3dMD photogrammetric images. Am J Med Genet A. 2005 Oct;138A(3):247-53. http://dx.doi.org/10.1002/ajmg.a.30959. PMid:16158436.

5. Ferrario VF, Sforza C, Miani A, Tartaglia G. Craniofacial morphometry by photographic evaluations. Am J Orthod Dentofacial Orthop. 1993 Apr;103(4):327-37. http://dx.doi.org/10.1016/0889-5406(93)70013-E. PMid:8480698.

6. Lane C, Harrell W Jr. Completing the 3-dimensional picture. Am J Orthod Dentofacial Orthop. 2008 Apr;133(4):612-20. http://dx.doi. org/10.1016/j.ajodo.2007.03.023. PMid:18405826.

7. Wong JY, Oh AK, Ohta E, Hunt AT, Rogers GF, Mulliken JB, et al. Validity and reliability of craniofacial anthropometric measurement of 3D digital photogrammetric images. Cleft Palate Craniofac J. 2008 May;45(3):232-9. http://dx.doi.org/10.1597/06-175. PMid:18452351.

8. Germec-Cakan D, Canter HI, Nur B, Arun T. Comparison of facial soft tissue measurements on three-dimensional images and models obtained with different methods. J Craniofac Surg. 2010 Sep;21(5):1393-9. http://dx.doi.org/10.1097/SCS.0b013e3181ec6976. PMid:20856027.

9. Deli R, Di Gioia E, Galantucci LM, Percoco G. Automated landmark extraction for orthodontic measurement of faces using the 3-camera photogrammetry methodology. J Craniofac Surg. 2010 Jan;21(1):87-93. http://dx.doi.org/10.1097/SCS.0b013e3181c3ba74. PMid:20072024.

10. Gor T, Kau CH, English JD, Lee RP, Borbely P. Three-dimensional comparison of facial morphology in white populations in Budapest, Hungary, and Houston, Texas. Am J Orthod Dentofacial Orthop. 2010 Mar;137(3):424-32. http://dx.doi.org/10.1016/j.ajodo.2008.12.022. PMid:20197183.

11. Weinberg SM, Naidoo S, Govier DP, Martin RA, Kane AA, Marazita ML. Anthropometric precision and accuracy of digital three-dimensional photogrammetry: comparing the Genex and 3dMD imaging systems with one another and with direct anthropometry. J Craniofac Surg. 2006 May;17(3):477-83. http://dx.doi.org/10.1097/00001665-200605000-00015. PMid:16770184.

12. See MS, Roberts C, Nduka C. Age- and gravity-related changes in facial morphology: 3-dimensional analysis of facial morphology in motherdaughter pairs. J Oral Maxillofac Surg. 2008 Jul;66(7):1410-6. http://dx.doi.org/10.1016/j.joms.2007.12.041. PMid:18571025.

13. Ladeira PRS, Bastos EO, Vanini JV, Alonso N. Use of stereophotogrammetry for evaluating craniofacial deformities: a systematic review. Rev Bras Cir Plást. 2013 Mar;28(1):147-55. http://dx.doi.org/10.1590/S1983-51752013000100025.

14. Choe KS, Sclafani AP, Litner JA, Yu GP, Romo T 3rd. The Korean American woman's face: anthropometric measurements and quantitative analysis of facial aesthetics. Arch Facial Plast Surg. 2004 Jul-Aug;6(4):244-52. http://dx.doi.org/10.1001/archfaci.6.4.244. PMid:15262719.

15. Porter JP. The average African American male face: an anthropometric analysis. Arch Facial Plast Surg. 2004 Mar-Apr;6(2):78-81. http://dx.doi. org/10.1001/archfaci.6.2.78. PMid:15023793.

16. Farkas LG, Katic MJ, Forrest CR, Alt KW, Bagic I, Baltadjiev G, et al. International anthropometric study of facial morphology in various ethnic groups/races. J Craniofac Surg. 2005 Jul;16(4):615-46. http://dx.doi.org/10.1097/01.scs.0000171847.58031.9e. PMid:16077306.

17. Baik HS, Jeon JM, Lee HJ. Facial soft-tissue analysis of Korean adults with normal occlusion using a 3-dimensional laser scanner. Am J Orthod Dentofacial Orthop. 2007 Jun;131(6):759-66. http://dx.doi.org/10.1016/j.ajodo.2005.08.038. PMid:17561054.

18. Farkas LG, Katic MJ, Forrest CR. Comparison of craniofacial measurements of young adult African-American and North American white males and females. Ann Plast Surg. 2007 Dec;59(6):692-8. http://dx.doi.org/10.1097/01.sap.0000258954.55068.b4. PMid:18046155.

19. Ozdemir ST, Sigirli D, Ercan I, Cankur NS. Photographic facial soft tissue analysis of healthy Turkish young adults: anthropometric measurements. Aesthetic Plast Surg. 2009 Mar;33(2):175-84. http://dx.doi.org/10.1007/s00266-008-9274-z. PMid:19089493.

20. Ferrario VF, Sforza C, Poggio CE, Tartaglia G. Distance from symmetry: a three-dimensional evaluation of facial asymmetry. J Oral Maxillofac Surg. 1994 Nov;52(11):1126-32. http://dx.doi.org/10.1016/0278-2391(94)90528-2. PMid:7965306.

21. Douglas TS. Image processing for craniofacial landmark identification and measurement: a review of photogrammetry and cephalometry. Comput Med Imaging Graph. 2004 Oct;28(7):401-9. http://dx.doi.org/10.1016/j.compmedimag.2004.06.002. PMid:15464879.

22. Jayaratne YSN, Deutsch CK, Zwahlen RA. Normative findings for periocular anthropometric measurements among Chinese young adults in Hong Kong. Biomed Res Int. 2013, (821428):1-5. http://dx.doi.org/10.1155/2013/821428.

\section{CONFLICTS OF INTERESTS}

The authors declare no conflicts of interest.

\section{${ }^{*}$ CORRESPONDING AUTHOR}

Alvaro Augusto Junqueira Júnior, FORP - Faculdade de Odontologia de Ribeirão Preto, USP - Universidade de São Paulo, Avenida Maria de Jesus Condeixa, 655, Apto. 603, Bloco 1, Jardim Pala Travassos, 14091-230 Ribeirão Preto - SP, Brasil, e-mail: alvarojunqueira@usp.br 